\title{
Effect of strontium concentration on thermoluminescence glow curve of copper doped lithium magnesium borate glass
}

\author{
Nurul Anati Salleh ${ }^{a,}{ }^{*}$, Abdul Rahman Tamuri ${ }^{b}$, Mohammad Alam Saeed c \\ ${ }^{a, b}$ Department of Physics, Faculty of Science, Universiti Teknologi Malaysia, 81310 UTM Johor Bahru, Johor, Malaysia \\ c Division of Science and Technology, University of Education, Lahore, Pakistan \\ * Corresponding author: nurulanati@yahoo.com
}

\section{Article history}

Received 17 February 2017

Accepted 4 July 2017

\begin{abstract}
This study investigates the thermoluminescence $(\mathrm{TL})$ properties of copper $\left(\mathrm{Cu}_{2} \mathrm{O}\right)$ doped lithium magnesium borate (LMB) glass co-doped with strontium ( $\mathrm{SrO}$ ) subjected to Co-60 gamma irradiation. The glass samples based on $(69.95-x) \mathrm{B}_{2} \mathrm{O}_{3}-20 \mathrm{Li}_{2} \mathrm{O}-10 \mathrm{MgO}: 0.05 \mathrm{Cu}_{2} \mathrm{O} ; \mathrm{xSrO}$, where $0.001 \leq \mathrm{x} \leq$ $0.03 \mathrm{~mol} \%$ were prepared by melt-quenching technique. The amorphous state of both $\mathrm{Sr}$ co-doped and Cu-doped LMB glass samples were confirmed by using X-Ray Diffraction (XRD). For this study, the optimum TL Response was found with $0.003 \mathrm{~mol} \%$ of Sr concentration with TL intensity $3.6 \times 10^{5}$ $\mathrm{nCg}^{-1}$. The maximum peak temperature of glow curve for all glass samples was observed at $170-200$ ${ }^{\circ} \mathrm{C}$. The annealing procedure for the studied samples was determined at $100^{\circ} \mathrm{C}$ for 20 minutes with the heating rate of $7^{\circ} \mathrm{C} \mathrm{s}^{-1}$.
\end{abstract}

Keywords: Thermoluminescence, borate glass, Co-60 gamma ray,

\section{INTRODUCTION}

Thermoluminescence dosimeter (TLD) is a device to measure the ionizing radiation dose and known as the cost-effective technique of radiation dosimetry. TLDs are widely used in many fields such as radiation protection, personal monitoring, environmental monitoring and industry applications (Furetta, 2003; Kortov, 2010). Recently, many type of studies have been conducted to find out a suitable and better dosimeter materials. Borate glass has been widely studied because of its near tissue equivalence absorption coefficient, higher sensitivity, low cost and easy preparation. However, the disadvantage of pure borate glass to be used as radiation dosimeter is its hygroscopic nature (Santiago et al., 2001). Therefore, the addition of different modifiers can improve the intensity, enhance the chemical durability of the borate glass, also interrupt the glass network and reduce the viscosity of the glass (Jiang et al., 2010).

Many researchers has studied TL properties of lithium borate $\left(\mathrm{Li}_{2} \mathrm{~B}_{4} \mathrm{O}_{7}\right)$. It was discovered first by Schulman et al., (1965) in his study on lithium borate compound. Lithium borate glass becomes attractive due to its near tissue equivalence absorption coefficient $\left(Z_{\mathrm{ef}}\right.$ $=7.3$ ), low cost and easy handling process (Schulman et al., 1965). Magnesium oxide $(\mathrm{MgO})$ was used as a modifier to determine the phase relations and structural properties of lithium magnesium borate (Wu et $a l .$, 2002). The TL properties of lithium magnesium borate doped with a different concentration of $\mathrm{MgO}$ has been studied by Elkholy (2010).

The addition of dopants such as transition metals, rare earth and alkaline can enhance the TL properties of lithium magnesium borate glass. The recent studies reveal that $\mathrm{Tb}^{3+}$ doped lithium magnesium borate exhibits good linear TL response, good reusability and sensitivity, simple annealing procedure and is near tissue equivalent, as well as stable for many years (Anishia et al., 2011). Alajerami et al., reported that the thermoluminescence characteristics of lithium potassium borate (LKB) co-doped with $\mathrm{CuO}$ and $\mathrm{MgO}$ has $\mathrm{Z}_{\mathrm{eff}}=8.55$, good reproducibility and good linear dose response at a wide range of irradiation dose (Alajerami et al., 2013). The introduction of transition metals (TM) elements improves the efficiency of the glass. Copper doped borate glass has been found to be the most successful dopant that shows excellent TL properties. By adding copper as a dopant, could improve the stability, enhance the TL sensitivity and perform a good chemical stability due to its non-hygroscopic nature. The addition of $\mathrm{Cu}$ as an activator in borate glass displays high sensitivity, low fading, linearity in wide dose range and effective atomic number close to human tissue (Alajerami et al., 2014).

The co-dopant technique was used to overcome the quenching state and enhance the sensitivity for dopant (Elkholy, 2010; Alajerami et al.,2013). According to Evis et al., (2016), strontium was used for the first time as an activator agent for magnesium tetraborate (MBO) and thermoluminescence (TL) properties were determined using a TL reader. The results show that Sr play an important role in prolonging the after glow and the main TL peak was observed at $200^{\circ} \mathrm{C}$. It can be said that $\mathrm{Sr}^{2+}$ is a promising activator for $\mathrm{MBO}$ and $\mathrm{Sr}$-doped compound seem to be suitable for dosimetric applications (Evis et al., 2016). The present work is an attempt to investigate the effect of Sr concentrations on thermoluminescence (TL) properties of the copper doped lithium magnesium borate glass. By adding strontium as co-dopant in lithium magnesium borate glass doped copper are expected to improve the TL performance with high TL sensitivity and enhance the TL properties of the studied samples.

\section{EXPERIMENTAL}

\section{Materials and Methods}

All the glass samples were prepared by melt-quenching technique and the nominal compositions of the glass samples is shown in Table 1. The reagent chemicals used for glass preparation were borate oxide $\left(\mathrm{B}_{2} \mathrm{O}_{3}\right)$, magnesium oxide $(\mathrm{MgO})$, lithium oxide $\left(\mathrm{Li}_{2} \mathrm{O}\right)$, copper oxide $\left(\mathrm{Cu}_{2} \mathrm{O}\right)$ and strontium oxide $(\mathrm{SrO})$. The reagents were weighed by using analytical balance. The samples were mixed using milling machine for 
1 hour to obtain a homogeneous mixture. The samples were melted in alumina crucible for 1 hour at $1300^{\circ} \mathrm{C}$ in high temperature furnace. After melting, the samples were poured into a stainless plate and annealed at $400^{\circ} \mathrm{C}$ for 3 hours. The glasses were left inside the furnace to avoid thermal stress and cooled down slowly to the room temperature. The samples were broken off into small pieces and weighed in the range of $0.01-0.03 \mathrm{~g}$ before exposing to Co- 60 gamma rays at Universiti Kebangsaan Malaysia (UKM), Bangi. X-Ray Diffraction (XRD) method was used to characterize amorphous phase of the samples.

Table 1 Nominal composition of prepared glass samples.

\begin{tabular}{cccccc}
\hline \multirow{2}{*}{$\begin{array}{c}\text { Sample } \\
\text { No. }\end{array}$} & \multicolumn{5}{c}{ Composition $(\mathbf{\pm 0 . 0 1}$ mol\%) } \\
\cline { 2 - 6 } & $\mathbf{B}_{2} \mathbf{O}_{3}$ & $\mathbf{L i}_{2} \mathbf{O}$ & $\mathbf{M g O}$ & $\mathbf{C u}_{2} \mathbf{O}$ & SrO \\
\hline S1 & 69.990 & 20.00 & 10.00 & 0.01 & 0.000 \\
S2 & 69.970 & 20.00 & 10.00 & 0.03 & 0.000 \\
S3 & 69.950 & 20.00 & 10.00 & 0.05 & 0.000 \\
S4 & 69.930 & 20.00 & 10.00 & 0.07 & 0.000 \\
S5 & 69.900 & 20.00 & 10.00 & 0.10 & 0.000 \\
S6 & 69.700 & 20.00 & 10.00 & 0.30 & 0.000 \\
S7 & 69.920 & 20.00 & 10.00 & 0.05 & 0.030 \\
S8 & 69.940 & 20.00 & 10.00 & 0.05 & 0.010 \\
S9 & 69.941 & 20.00 & 10.00 & 0.05 & 0.009 \\
S10 & 69.943 & 20.00 & 10.00 & 0.05 & 0.007 \\
S11 & 69.945 & 20.00 & 10.00 & 0.05 & 0.005 \\
S12 & 69.947 & 20.00 & 10.00 & 0.05 & 0.003 \\
S13 & 69.949 & 20.00 & 10.00 & 0.05 & 0.001 \\
\hline
\end{tabular}

\section{RESULTS AND DISCUSSION}

\section{X-Ray diffraction (XRD) analysis}

$\mathrm{X}$-Ray diffraction (XRD) method was used to determine if the samples were in amorphous or crystalline phase. Fig. 1 shows an XRD pattern of the $\mathrm{Cu}$-doped $(0.05 \mathrm{~mol} \%)$ and $\mathrm{Sr}$ co-doped $(0.003 \mathrm{~mol} \%)$ glass samples in the range of $10^{\circ} \leq \theta \leq 90^{\circ}$. The results confirm that the samples are in an amorphous state with the presence of broad peaks and no discrete or continuous sharp peaks on the spectra pattern.

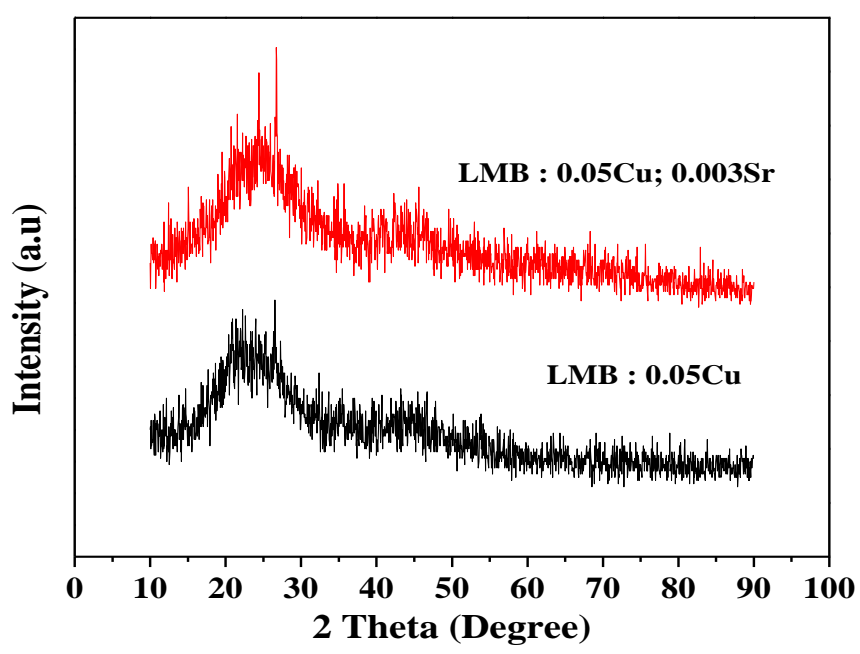

Fig. 1 XRD pattern of copper doped and strontium co-doped lithium magnesium borate glass.

\section{TL glow curve}

One of the important features of TL phenomena is understanding glow curve of the studied samples. They are plotted as light intensity against the temperature. The shape and the position of the glow curve can reveal the type of trapping states of the glass samples. A good TL material and ideal glow curve should displays a single sharp peak positioned between $170{ }^{\circ} \mathrm{C}$ and $250^{\circ} \mathrm{C}$ (Pekpak et al., 2010; Lim et al., 2015).

The doped sample of composition $(69.95-\mathrm{x}) \mathrm{B}_{2} \mathrm{O}_{3}-20 \mathrm{Li}_{2} 0$ $10 \mathrm{MgO}: 0.05 \mathrm{Cu}_{2} \mathrm{O} ; \mathrm{xSrO}$ was co-doped with different $\mathrm{Sr}$ concentrations $(0.001,0.003,0.005,0.007,0.009,0.10$ and $0.30 \mathrm{~mol} \%)$. The samples were exposed to $50 \mathrm{~Gy}$ Co- 60 gamma ray. Fig. 2 (a) illustrates the peak temperature that is observed at $170{ }^{\circ} \mathrm{C}$ with the $0.05 \mathrm{~mol} \% \mathrm{Cu}_{2} \mathrm{O}$ concentration. This $0.05 \mathrm{~mol} \% \mathrm{Cu}$ concentration is chosen as the optimum concentration as it produces highest TL intensity with the lowest standard deviation as shown in Fig. 2 (b). Fig. 3 (a) exhibits the glow curve obtained for various $\mathrm{Sr}$ concentrations. The figure shows that the highest TL intensity is obtained for the sample with $0.003 \mathrm{~mol} \%$ of $\mathrm{Sr}$ concentration and the TL peak is located at around $176^{\circ} \mathrm{C}$. This sample is chosen as the optimum concentration as it produces the lowest standard deviation and the highest TL response as shown in Fig. 3 (b). Therefore, the sample with $0.003 \mathrm{~mol} \% \mathrm{Sr}$ was selected for further investigation for its TL properties.

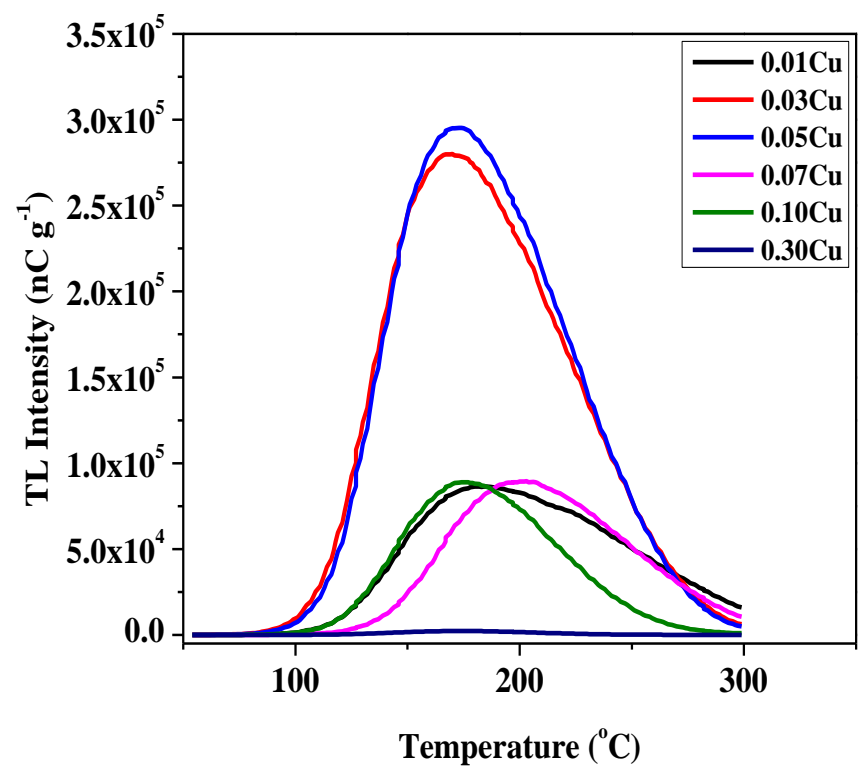

(a)

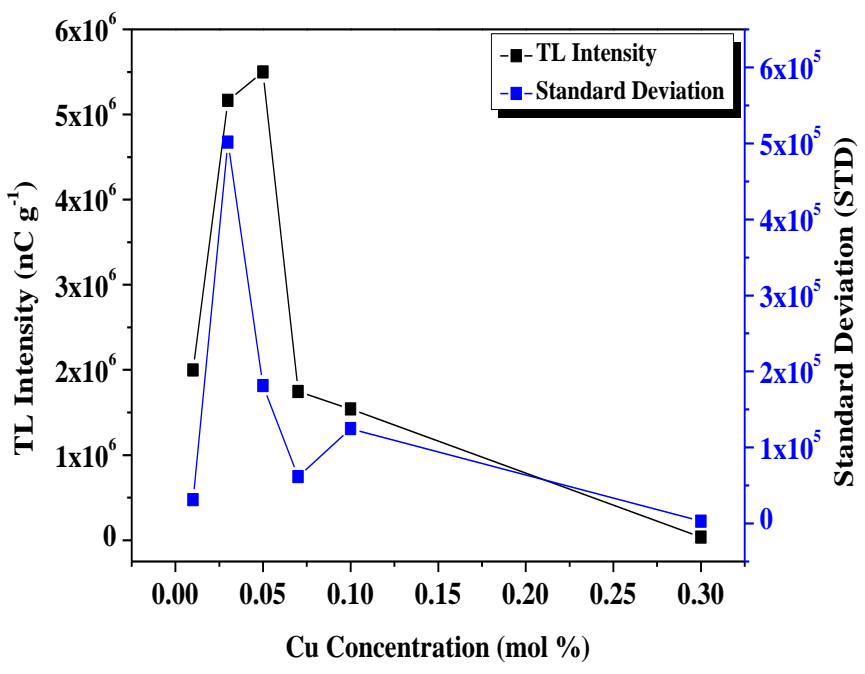

(b)

Fig. 2 Graphs of (a) TL glow curve and (b) TL intensity with standard deviation for $\mathrm{LMB}$ doped with a different concentration of $\mathrm{Cu}_{2} \mathrm{O}$.

In their previous work, Evis et al., (2016) doped magnesium tetraborate $(\mathrm{MBO})$ with $\mathrm{Sr}^{2+}$ at different concentrations. The results show that $0.25 \mathrm{~mol} \% \mathrm{Sr}$ ratio gives the main TL peak with the highest intensity at $200{ }^{\circ} \mathrm{C}$ just like an ideal case. The intensities of TL glow 
peaks increases with increasing the $\mathrm{Sr}$ concentration until $0.25 \mathrm{~mol} \%$ and then drastically decreases until $2.5 \mathrm{~mol} \%$. The TL intensity of $\mathrm{Sr}^{2+}$ doped sample was $3.1 \times 10^{4} \mathrm{nC} \mathrm{g}^{-1}$ (Evis et al., 2016). In the present study, the addition of $\mathrm{Cu}_{2} \mathrm{O}$ on LMB enhances the intensity by 98 times of pure LMB. From Fig. 2 (a) displays that TL glow peaks increase with the increasing of copper concentration until $0.05 \mathrm{~mol} \%$ and then a reduction of TL glow curve intensity is observed from $0.07 \mathrm{~mol} \%$ to $0.30 \mathrm{~mol} \% \mathrm{Cu}$. This phenomenon attributing to the quenching effect which occurs due to the competition between traps and non-radiative transitions (Depci et al., 2011; Souza et al., 2014; Lim et al., 2015).

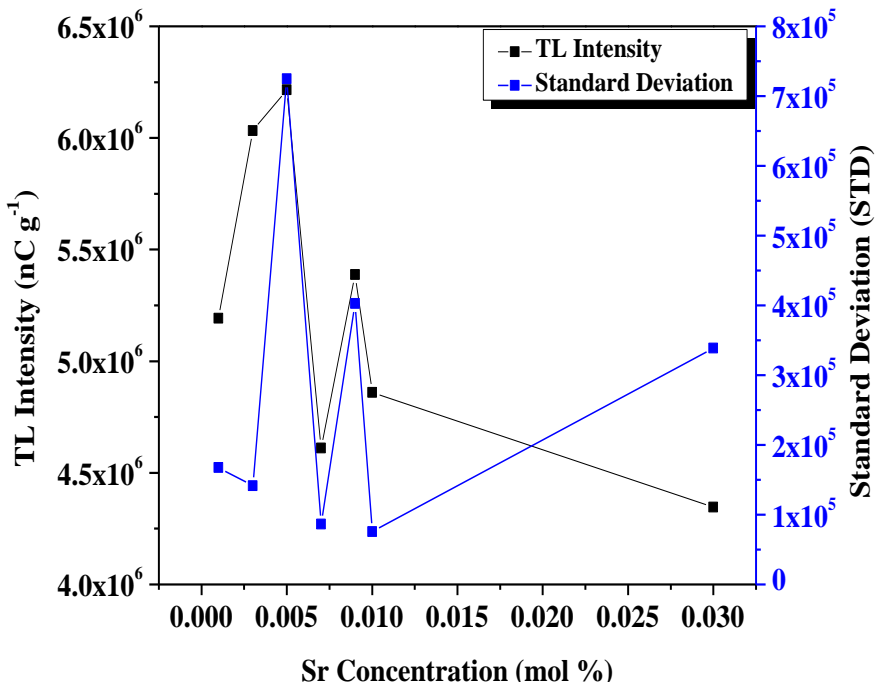

(a)

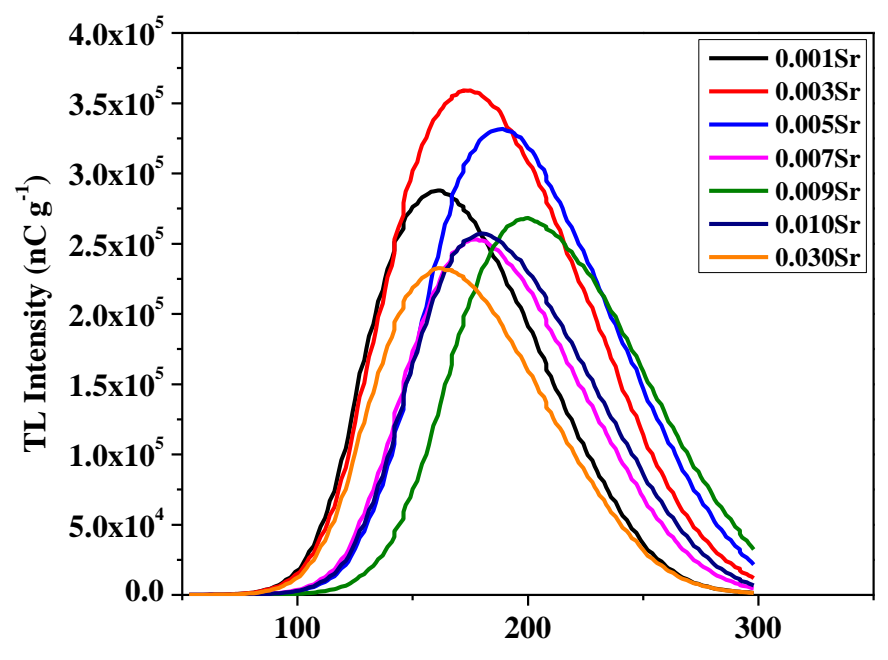

Temperature $\left({ }^{\circ} \mathrm{C}\right)$

(b)

Fig. 3 Graphs of (a) TL glow curve and (b) TL intensity with standard deviation for LMB co-doped with $0.05 \quad \mathrm{~mol} \% \quad \mathrm{Cu}_{2} \mathrm{O}$ at different concentrations of $\mathrm{SrO}$.

For the strontium co-doped LMB:Cu glass samples, the optimum concentration is observed at $0.003 \mathrm{~mol} \% \mathrm{Sr}$ as shown in Fig. 3 (a). The presence of strontium concentrations $(0.003 \mathrm{~mol} \%)$ in LMB:Cu glass samples enhances the TL intensity of LMB:Cu glass sample by a factor of 1.2 which gives the highest TL intensity of $3.6 \times 10^{5} \mathrm{nC} \mathrm{g}^{-1}$. The intensity of LMB:Cu; $0.003 \mathrm{~mol} \% \mathrm{Sr}$ glass sample increases with the increase of $\mathrm{Sr}$ concentration from 0.001 to $0.003 \mathrm{~mol} \%$. However, the $\mathrm{TL}$ intensity drops with the increasing $\mathrm{SrO}$ from $0.005 \mathrm{~mol} \%$ to 0.03 mol\% Sr. After adding Sr into LMB:Cu glass, no big difference observed in the glow curve structures off all the samples. This shows that $\mathrm{SrO}$ is a concentration-independent character (Evis et al., 2016). The differences are observed on the TL intensity and the temperature is slightly shifted to $174{ }^{\circ} \mathrm{C}$. This behavior is ascribed to the ability of $\mathrm{Sr}$ ions to create deeper traps in the host (Alajerami et al, 2013).

\section{Annealing procedure}

The pre-annealing procedure was carried out for all the glass samples. This procedure was done to erase any irradiation memory from the TL material. The first step is varying annealing temperature from $100^{\circ} \mathrm{C}$ to $400^{\circ} \mathrm{C}$ at a constant annealing time of 60 minutes. The samples were exposed to Cobalt- 60 gamma ray at a dose of $50 \mathrm{~Gy}$. The average TL intensity and its standard deviation were read for three individual measurements using TLD reader and the graph was plotted as shown in Fig. 4. The result shows the lowest standard deviation at $100{ }^{\circ} \mathrm{C}$ with the highest TL intensity. This annealing temperature was chosen as the best annealing temperature.

From the previous step, the second step is varying the annealing time from 10 to 60 minutes at a constant temperature of $100^{\circ} \mathrm{C}$. Fig. 5 illustrates the TL graph response and its standard deviation as a function of annealing time. The figure shows that the highest TL intensity is obtained at an annealing time of 20 minutes and with the lowest standard deviation. Therefore, annealing procedure of the studied samples was achieved at $100^{\circ} \mathrm{C}$ for 20 minutes.

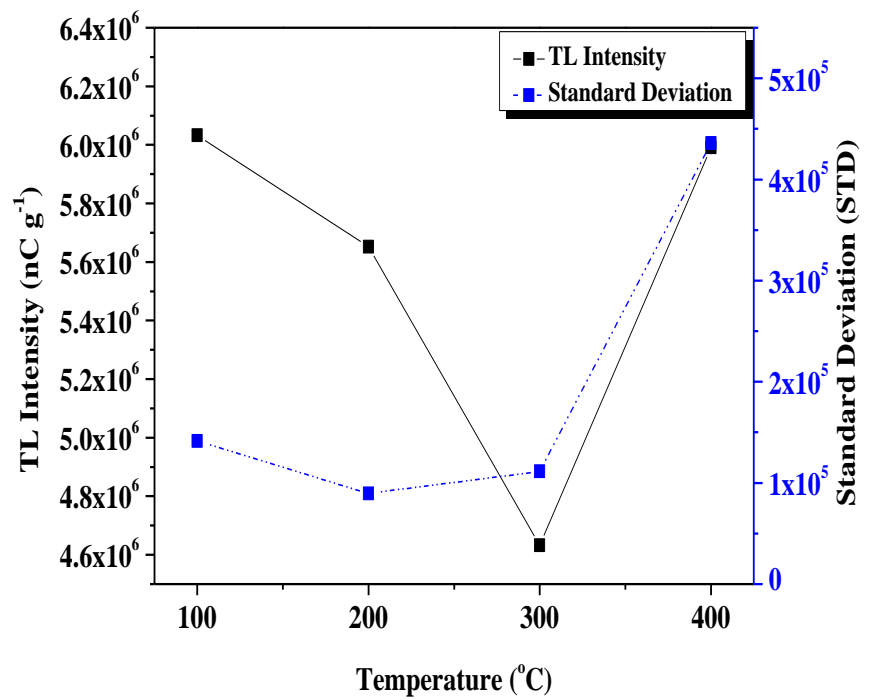

Fig. 4 Graphs of TL intensity at various annealing temperatures of LMB:0.05Cu;0.003Sr glass sample.

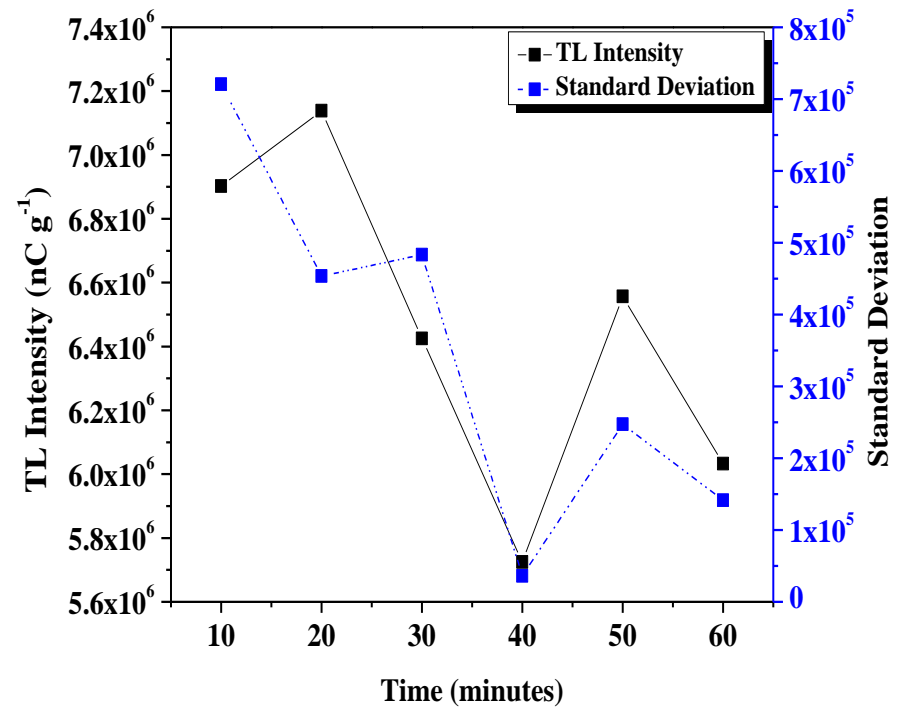

Fig. 5 Graphs of TL intensity at various annealing times of LMB:0.05Cu;0.003Sr glass sample.

\section{Heating rate}

The heating rate is one of the time temperature profile (TTP) setups of the TLD reader. The TTP of the TLD reader was studied in order to obtain good TL glow curve with high TL intensity. In this study, the glass of composition $69.947 \mathrm{~B}_{2} \mathrm{O}_{3}-20 \mathrm{Li}_{2} \mathrm{O}-10 \mathrm{MgO}: 0.05 \mathrm{Cu}_{2} \mathrm{O}$; 
$0.003 \mathrm{SrO}$ was used for heating rate setting. All the studied samples were annealed with the same annealing procedure as mention in the previous section. The samples were irradiated with 50 Gy of Cobalt- 60 gamma source. The TL intensity of the sample was recorded using TLD reader 4500 at a different heating rate from 1 to $10^{\circ} \mathrm{C} \mathrm{s}^{-1}$.

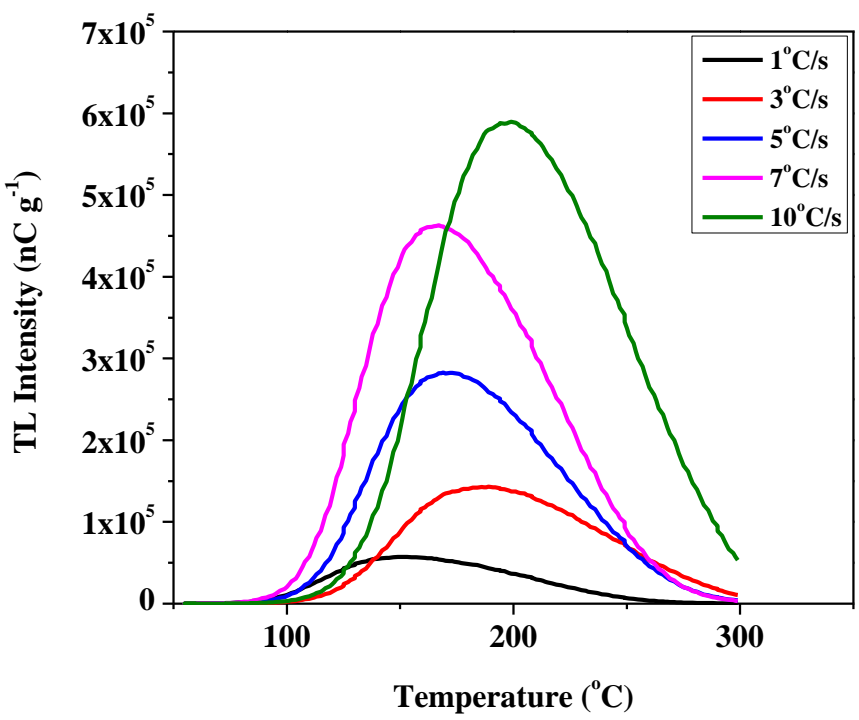

(a)

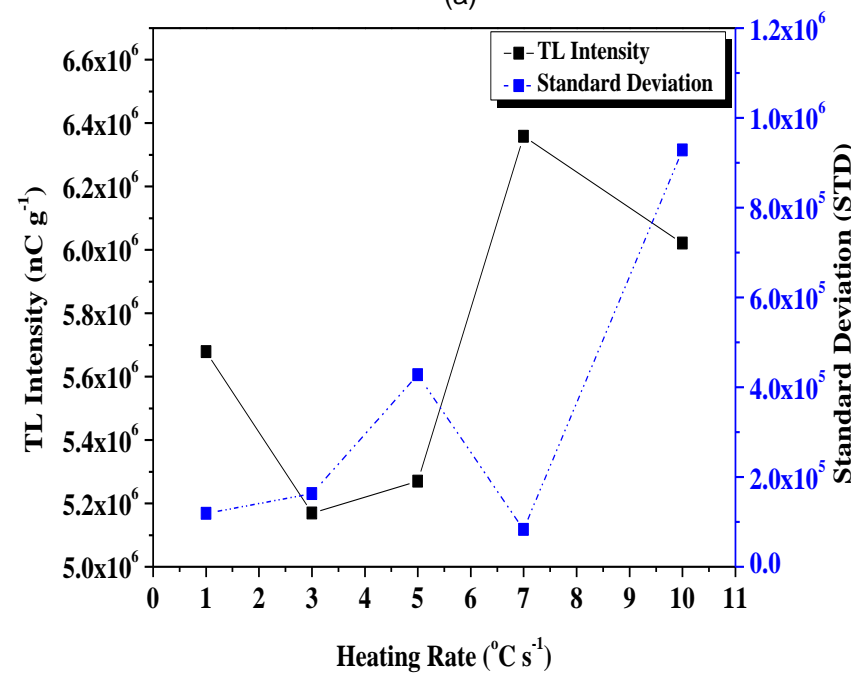

(b)

Fig. 6 Graphs of (a) TL glow curve and (b) TL intensity with standard deviation at the various heating rate for $\mathrm{LMB}: 0.05 \mathrm{Cu} ; 0.003 \mathrm{Sr}$.

Fig. 6 (a) represents the TL glow curve of Sr co-doped $(0.003$ mol\%) lithium magnesium borate glass doped copper with different heating rates from 1 to $10^{\circ} \mathrm{C} \mathrm{s}^{-1}$. The TL intensity and the position of the glow curve peak depend on the heating rate. When the heating rate increases, the TL intensity also increases and the glow curve peak shifts to a higher temperature. From Fig. 6 (b), the average TL intensity against standard deviations at various heating rates was plotted. From Fig. 6 (a), it can be seen that the highest TL intensity is observed at 10 ${ }^{\circ} \mathrm{C} \mathrm{s}^{-1}$, however the highest TL intensity is obtained at the heating rate $7^{\circ} \mathrm{C} \mathrm{s}^{-1}$ which has the lowest standard deviation as shown in Figure 6 (b). The glow curve peak of heating $7{ }^{\circ} \mathrm{C} \mathrm{s}^{-1}$ is located at $170-200{ }^{\circ} \mathrm{C}$ and it obeys the ideal characteristics of the glow curve (Pradhan, 1981). Therefore, for this study, heating rate $7{ }^{\circ} \mathrm{C} \mathrm{s}^{-1}$ was chosen as the best heating rate. The TTP setup used for the studied samples are as follow: preheat temperature at $50{ }^{\circ} \mathrm{C}$ at $0 \mathrm{~s}$; readout temperature at $100{ }^{\circ} \mathrm{C}$ for $35.71 \mathrm{~s}$ with the heating rate of $7^{\circ} \mathrm{C} \mathrm{s}-1$.

\section{CONCLUSION}

In the current study, strontium co-doped and copper doped lithium magnesium borate glasses were successfully prepared by melt- quenching technique. The XRD analysis confirms that the glass samples are in the amorphous state. The optimum strontium concentration is found to be $0.003 \mathrm{~mol} \%$. The annealing procedure of $100{ }^{\circ} \mathrm{C}$ for 20 minutes is determined for all studied samples. The best heating rate obtained from the samples under study is $7{ }^{\circ} \mathrm{C} \mathrm{s}^{-1}$. Therefore, this sample was chosen to be used for further investigation to determine its TL properties such as sensitivity, linearity, reproducibility, fading and effective atomic number.

\section{ACKNOWLEDGEMENT}

The authors acknowledge gratefully to Ministry of Education (MOE) of Malaysia for providing the financial support under Grant No. Q.J130000.2526.10H20. Thankful to Universiti Kebangsaan Malaysia for providing irradiation facility and Faculty of Science, Universiti Teknologi Malaysia for providing experimental facilities for this research

\section{REFERENCES}

Anishia, S. R., Jose, M. T., Annalakshmi, O., Ramasamy, V. 2011. Thermoluminescence properties of rare earth doped lithium magnesium borate phosphors. Journal of Luminescence, 131(12), 2492-2498.

Alajerami, Y. S. M., Hashim, S., Ramli, A. T., Saleh, M. A., Kadni, T. 2013. Thermoluminescence characteristics of the $\mathrm{Li}_{2} \mathrm{CO}_{3}-\mathrm{K}_{2} \mathrm{CO}_{3}-\mathrm{H}_{3} \mathrm{BO}_{3}$ glass system co-doped with $\mathrm{CuO}$ and $\mathrm{MgO}$. Journal of Luminescence, 143, 1-4.

Alajerami, Y. S. M., Hashim, S., Goshal, S. K., Bradley, D. A., Mhareb, M., Saleh, M. A. 2014. Copper doped borate dosimeters revisited. Journal of Luminescence, 155, 141-148.

Depci, T., Ozbayoglu, G., \& Yilmaz, A 2011. Synthesis and thermoluminescence properties of rare earth oxides (Y, Ce-Lu) doped lithium triborate. Journal of Rare Earths, 29 (6) , 618-622.

Elkholy, M. M. 2010. Thermoluminescence of $\mathrm{B}_{2} \mathrm{O}_{3}-\mathrm{Li}_{2} \mathrm{O}$ glass system doped with MgO. Journal of Luminescence, 130 (10), 1880-1892.

Evis, D., Yucel, A., Kizilkaya, N., Depci, T., Kafadar, V. E., Ozturk, E., \& Yildirim, R. G. 2016. A new activator strontium for magnesium tetraborate: PL and TL studies. Journal of Applied Radiation and Isotopes, 116, 138-142. Furetta, C. 2003. Handbook of Thermoluminescence. World Scientific.

Jiang, L. H., Zhang, Y. L., Li, C. Y., Hao, J. Q., Su, Q. 2010. Thermoluminescence studies of $\mathrm{LiSrBO}_{3}: \mathrm{Re}^{3+}(\mathrm{RE}=\mathrm{Dy}, \mathrm{Tb}, \mathrm{Tm}$ and $\mathrm{Ce}$ ). Journal of Applied Radiation and Isotopes, 68(1), 196-200.

Kortov, V. S. 2010. Nanophosphors and outlooks for their use in ionizing radiation detection. Radiation Measurements, 45 (3-6), 512-515.

Lim, T. Y., Wagiran, H., Hussin, R., \& Hashim, S. 2015. Thermoluminescence response of dysprosium doped strontium tetraborate glasses subjected to electron irradiations. Journal of Applied Radiation and Isotopes, 102, 10-14.

Pekpak, E., Yilmaz, A., \& Ozbayoglu, G. 2010. An overview on preparation and TL characterization of lithium borates for dosimetric use. The Open Mineral Processing Journal, 3, 14-24.

Pradhan, A. S. 1981. Thermoluminescence Dosimetry and its Applications. Radiation Protection Dosimetry. 1(3), 153-167.

Santiago, M., Graseli, C., Caselli, E., Lester, M., Lavat, A. and Spano, F. 2001. Thermoluminescence of $\mathrm{SrB}_{4} \mathrm{O}_{7}$ :Dy. Physica Status Solidi (A), 185 (2), 285 289.

Schulman, J. H., Kirk, R. D and West, E.J. 1965. Use of lithium borate for thermoluminescence dosimetry. Proceedings of the International Conference on Luminescence Dosimetry, Conf: 650637. 25, 113-117.

Souza, L. F., Antonio, P. L., Caldas, L. V. E., \& Souza, D. N. 2015. Neodymium as a magnesium tetraborate matrix dopant and its applicability in dosimetry and as a temperature sensor. Journal of Nuclear Instruments and Methods in Physics Research A. 784, 9-13.

Wu, L., Chen, X. L., Tu, Q. Y., He, M., Zhang, Y., Xu, Y. P. 2002. Phase relations in the system $\mathrm{Li}_{2} \mathrm{O}-\mathrm{MgO}-\mathrm{B}_{2} \mathrm{O}_{3}$. Journal of Alloys and Compounds. 333(1-2), 154-158. 